\title{
Analisa Hubungan Antara Kompensasi, Promosi Jabatan dengan Kinerja Karyawan
}

\author{
Dedy Syahyuni ${ }^{1^{*}}$ \\ Fakultas Ekonomi dan Bisnis Universitas Bina Sarana Informatika \\ Jl. Kramat Raya No.98 Senen 10450 Jakarta Pusat \\ "Email : deddy.ddn@bsi.ac.id
}

Naskah diterima 13 September 2021, Revisi 2 Oktober 2021, Terbit 29 Oktober 2021

DOI: doi.org/10.21107/pamator.v14i2.11210

\begin{abstract}
Employee performance or employee work performance is one of the keys to improving and maximizing organizational functions, either government organizations or private organizations (companies). With good employee performance, companies or government organizations can work effectively and efficiently because all work can be done in the right way and the use of all resources (time, cost and so on) can be used optimally. Various efforts have been made to increase and improve the level of employee performance; some have tried to maximize the work motivation component and so on. This paper tries to connect the compensation variables, job promotion and its relation to employee performance. From the calculation results, it is found that there is a relationship of 0.487 or a moderate level relationship between the compensation variable and the answer promotion with employee performance. The place for data collection was carried out at BPJS Ketenagakerjaan, Depok Branch, where respondents totaled 40 employees with a significance level of 5\%.
\end{abstract}

Key words: compensation, job promotion, performance

\section{PENDAHULUAN}

Pada masa pandemi karena adanya virus Covid-19 pada saat ini, keberadaan BPJS Ketenagakerjaan sebagai salah satu lembaga pemerintah yang bertugas memberikan jaminan pelayanan kesehatan (asuransi) kepada para tenaga kerja di Indonesia merupakan salah satu lembaga pemerintah yang memiliki tugas sangat, tentunya selain kementerian kesehatan dan Badan Nasional Penanggulangan Bencana. Saat ini semua warga Negara membutuhkan layanan kesehatan yang baik baik yang berhubugan langsung degnan virus Covid-19 atau tidak. Keadaan ini merupakan suatu hal yang wajar karena layana kesehatan merupakan salah satu kebutuhan pokok bagi setiap warga negara apalagi saat terjadi pandemi seperti saat ini. Akan tetapi kebutuhan akan layanan kesehatan oleh masyakarat tidak diikuti degan adanya kemampuan ekonomi dari setiap warga Negara. Adanya pandemi memaksa semua wargan negara dan warga dunia melaukan pembatasan sosial (social distancing) dan hal ini memaksa kita untuk melakukan cara baru dalam berkehidupan (New Normal).
Disinilah letak pentingnya keberadaan dari BPJS Ketenagakerjaan sebagai lebaga yang menjamin ausransi ketegakerjaan dari para anggotanya sehingga bila terjadi sesuatu yang tidak diinginkan dari para anggotanya maka lembaga dapat memberikan maanfat kepada ahli warisnya. Karena itu, kinerja yang baik dari lembaga ini menjadi hal yang snagat diperhatikan dan kinerja dari organisasi pasti berkaitan dengan kinerja dari anggota organsasi tersebut. Karyawan dari BPJS Ketenagakerjaan dituntut dapat tampil dengan performa yang baik sehingga pelayanan dapat berjalan secara maksimal, meskipun lembaga ini juga menerapkan pembatasan jam dan jumlah karyawan yang bekerja.

Menurut Werther dan Davis dalam Wibowo (2017), memberikan pengertian kompensasi sebagai apapun yang diterima oleh para pekerja sebagai tolak ukur atas sumbangan tenaga dan pikiran karyawan atau pekerja kepada perusahaan atau organisasi tempat mereka bekerja. Menurut Ivancevich dalam Kadarisman (2018), pengertian dari kompensasi adalah sebuah tugas dari bagian Human Resource 
Management atau HRM yang berkaitan dengan setiap hal berupa penghargaan atau reward yang diberikan perusahaan kepada karyawan sebagai imbal jasa atas pelaksanaan tugas dan tanggung jawab karyawan atau pegawai. dalam hal ini para karyawan atau pegawai menukarkan seluruh tenaga dan pikirannya untuk memperoleh penghargaan atau reward berupa uang dan non uang. Sebuah program kompensasi dari perusahaan harus dapat memberikan jawaban atas pertanyaan apa saja yang menyebabkan seseorang karyawan bekerja dan mengapa ada karyawan yang dapat bekerja dengan keras, sedangkan karyawan yang lain bekerja biasa saja (Hasibuam, 2016.

Pemanfaatan manajemen kinerja dalam sebuah organisasi bagi organisasi tersebut adalah sebagai cara penyesuaikan tujuan dari organisasi dengan tujuan dari tim dalam organisasi dan semua individu yang ada didalamnya (Wibowo, 2017). Pengertian dari kinerja karyawan atau prestasi kerja karyawan merupakan sebuah hasil kerja yang dilihat dari dimensi kualitas dan kuantitas yang telah diperoleh seorang karyawan didalam pelaksanaan tugas dan tanggung jawab yang dibebankan kepadanya dalam penyelesaian tugas yang embannya (Mangkunegara, 2019).

Selain dari itu, menurut (Mangkunegara, 2015) penggunaan istilah kinerja berakar kata dari istilah basaha inggris yaitu job performance terkadang disebut juga dengan actual performance atau artinya adalah prestasi kerja atau prestasi yang sesungguhnya telah diperoleh seorang karyawan. Selain dari itu, pengertian dari kinerja atau prestasi kerja karyawan adalah hasil kerja yang diperoleh secara kualitas dan juga kuantitas dari seorang karyawan dalam pelaksanaan tugas sesuai dengan pembebanan tanggung jawab yang telah diberikan karyawan atau tim tersebut.

Telah banyak kajian mengenai pembahasan betapa petingnya kinerja karyawan dan apa saja yang mempengaruhi kinerja karyawan. Dalam tulisan ini penulis mencoba melihat hubungan antara variabel kompensasi dan promosi jabatan terhadap kinerja karyawan pada BPJS Ketenagakerjaan Cabang depok dimana dalam penelitian ini pengumpulan data menggunakan bantuan dari google form yang diberikan kepada 40 orang kayawan.

\section{METODOLOGI}

Tulisan ini menggunakan metode penulisan kuantitatif deskriptif dimana angka signifikansi yang digunakan adalah $5 \%$. variabel yang digunakan adalah variabel kompensasi dan promosi jabatan sebagai variabel bebas dan yan gmenjdi variabel terikatnya adalah kinerja karyawaan. Pengambilan data menggunakan bantuan googleform dengan skala Likert dalam perhitungan jawabannya.

Perhitungan menggunakan bantuan aplikasi MS Excel dan Aplikasi SPSS versi 21 dan perhitungan yang dilakukan dalam tulisan ini adalah uji, validtas, reabilitas, uji klasik (Normalitas, Multikolinier dan Heterokedaksitas) lalu dilajutkan degan Uji Korelasi dan Uji Determinasi serta Uji Regresi sebagai uji terakhir. Tempat pengambilan data adalah lembaga pemerintah yaitu BPJS Ketenagakerjaan Cabang Depok, dimana responden berjumlah 40 orang karyawan degan metode pengambilan data yaitu dengan cara sebar kuisioner.

\section{HASIL DAN PEMBAHASAN}

Seperti yang sudah dibahas pada bagian sebelumnya pada tulisan ini penulis memilih variabel kompensasi dan promosi jawaban sebagai variabel benas dan sebagi variabel terikatnya adalah variabel kinerja karyawan. Pada tulisan ini penulis memilih kantor pelayanan BPJS Ketenagakerjaan cabang Depok sebagai tempat penelitian dengan jumalh karyawan sebanyak 40 orang karyawan. Sebelum melakukan pengujian yang lebih mendalam, berikut adalah uji awal dari data yang didapatkan dari sebar kuisioner yang menggunakan bantuan Google Form. Adapun data untuk hasil perhitungan tersebut dilakukan dengan menghitung atau melakukan Uji validitas dan uji Reabilitas. Untuk uji validitas ini penulis mengunakan tingkat signifikasi $5 \%$ dengan R- tabel sebesar 0,320. Hasil nya menunjukan bahwa 3 variabel pertanyaan yaitu kompensasi, promosi jabatan dan kinerja adalah valid. Adapun hasil dari uji reabilitas dari ketiga variabel tersebut dapat terlihat pada Tabel 1 di bawah ini. 
Tabel 1. Hasil Uji Reliabilitas

\begin{tabular}{|l|l|l|l|l|l|}
\hline \multicolumn{2}{|c|}{ Kompensasi } & \multicolumn{2}{c|}{ Promosi Jabatan } & \multicolumn{2}{c|}{ Kineria } \\
\hline Hasi & Keterangan & Hasil & Keterangan & Hasil & Keterangan \\
\hline 0,859 & Tinggi & 0,798 & Cukup & 0,881 & Tinggi \\
\hline
\end{tabular}

Hasil perhitungan uji reabilitas dengan bantuan SPSS atas ketiga variabel didapatkan hasil yang baik dimana pada variabel bebas kompensasi (X1) didapatkan hasil sebesar 0,859 atau reliabilitas tinggi. Lalu untuk variabel bebas yang kedua yaitu promosi jabatan (X2) didapatkan hasil sebesar 0,798 yang artinya reliabilitas cukup. Pada variabel terikat yaitu kinerja (Y) didapatkan hasil 0,881 yang artinya memiliki reliabilitas tinggi.

Tabel 2. Uji Normalitas (One-Sample Kolmogorov-Smirnov Test)

\begin{tabular}{|c|c|c|}
\hline & & $\begin{array}{c}\text { Unstandardized } \\
\text { Residual }\end{array}$ \\
\hline $\mathrm{N}$ & & 40 \\
\hline Normal & Mean & .0000000 \\
\hline Parameters ${ }^{a, b}$ & Std. Deviation & 2.89081721 \\
\hline & Absolute & .117 \\
\hline IViust Lxtrente & Positive & .110 \\
\hline Dinerences & Negative & -.117 \\
\hline Kolmogorov-S & rnov Z & .738 \\
\hline Asymp. Sig. (2 & iled) & .648 \\
\hline
\end{tabular}

Tabel 3. Uii Multi-kolinieritas

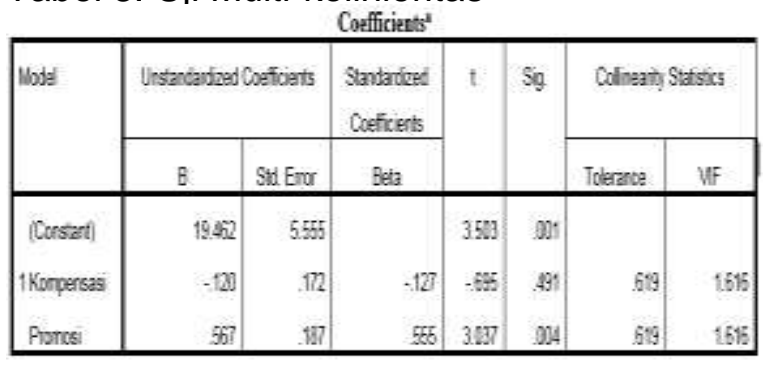

Hasil uji normalitas dinyatakan normal karena nilai Asymp Sig adalah 0,648 atau berada diatas 0,05. Hasil uji Multi-kolinearitas menunjukkan hasil torelance 0,619 dan nilai VIF adalah 1,616 atau dibawah 10,00, yang berarti tidak terdapat multi-kolinieritas. Dari hasil pengujian heterokedaksitas didapatkan bahwa tidak terdapat keraguan atau ketidakakuratan (heterokedaksitas), hal ini terlihat dari titik menyebar dan tidak berkumpul tidak berpola dan juga tidak berbentuk gelombang. Adapun hasil uji heterokedaksitas adalah sebagai berikut (Gambar 1).

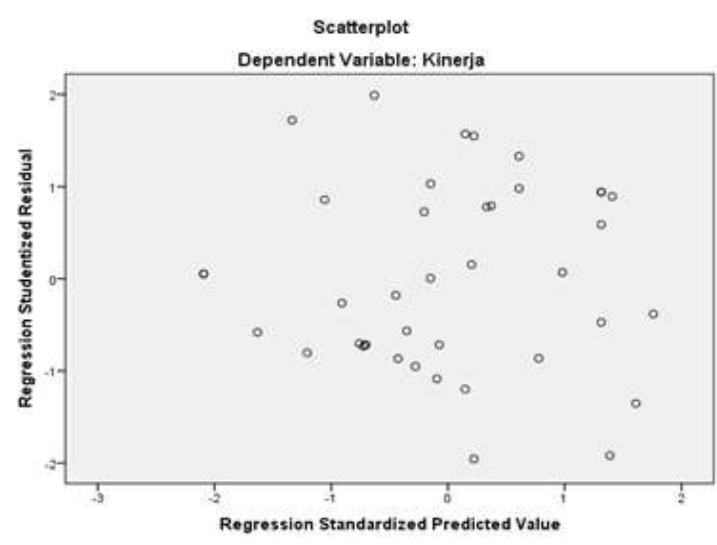

Gambar 1. Hasil Uji Heterokedaksitas

Tabel 4. Uji Korelasi dan Determinasi

Model Summan ${ }^{b}$

\begin{tabular}{|l|r|r|r|r|}
\hline Model & R & R Square & Adusted R Square & Stod Error of the Estinate \\
\hline 1 & $487 \mathrm{a}$ & 237 & 195 & 2968 \\
\hline
\end{tabular}

a Predictors: (Constant) Promosi, Kompensasi

b. Dependent Vanable; Kinerja

Dari tabel diatas dapat dilhat bahwa terdapat tingkat korelasi sebesar 0,487 yang berarti ada hubungan (korelasi) dengan tingkat sedang antara variabel bebas (kompensasi and promosi jabatan) dengan variabel terikat (kinerja karyawan). Lalu untuk hasil uji determinasi didapatkan hasil sebesar 0,237 yang artinya bahwa variabel bebas pada penelitian ini memberikan sumbangan atas terbentuknya variabel bebas sebesar 23,7 persen, dapat dikatakan pula bahwa sisanya atau 76,3 persen dipengaruhi oleh variabel lain yang tidak dapat dibahas disini karena tidak masuk dalam variabel yang ikut diuji.

Apabila dilihat dan dibandingkan dengan hasil penelitian sebelumnya maka didapatkan adanya beberapa kesamaan dalam kesimpulan hasil uji data masing masing penelitian. Seperti hasil penelitian (Mansyur, 2020) kompensasi insentif berpengaruh positif dan signifikan terhadap kinerja karyawan, hal ini ditunjukkan dengan hasil koefisen beta $(\beta) 2,678$, nilai signifikansi 0,038 . Variabel kompensasi insentif berpengaruh paling dominan terhadap kinerja karyawan. Hal ini dibuktikan untuk insentif dengan koefisien beta lebih tinggi dengan nilai signifikansi 0,038.

Variabel kompensasi memang sering kali memberikan kontribusi positif atas kinerja karyawan hal ini sejalan dengan pendapat dari Hasibuan (2008) seperti yang dikutip 
oleh (Talashina, 2020), menyatakan bahwa kompensasi dapat mempengaruhi kinerja karyawan dengan terlebih dahulu mempengaruhi kepuasan kerja. Hal yang hampir sama juga ditemukan dari hasil penelitian yang dilakukan oleh (Vahdist, 2017) didapatkan hasil yaitu variabel promosi jabatan berpengaruh positif terhadap terjadinya variabel kinerja pegawai dan hal ini dibuktikan dengan nilai koefisien sebesar 0,309 . Dari hasil tersebut dapat dijelaskan bahwa, bila semakin tinggi variabal promosi jabatan, maka semakin tinggi pula variabel kinerja pegawai. Sedangkan dari hasil peneltian yang dilakukan oleh (Rahayu, 2017) didapatkan hasil perhitungan dari analisis regresi sederhana diperoleh persamaan $Y=32,48+0,397 X$ yang artinya terdapat pengaruh sebesar 0,397 diantara promosi terhadap kinerja. Selain dari itu terdapat hasil sebesar 0,335 yang berarti terdapat hubungan dengan kategori sedang diantara variabel promosi dan variebel kinerja karyawan. Sedangkan dari hasil uji koefisien determinasi atas variabel promosi jabatan terhadap variabel kinerja sebesar $11,22 \%$ yang artinya sisanya sebesar $88,78 \%$ dipengaruhi oleh faktor lain yang tidak diteliti.

Berikutnya dari hasil penelitian yang dilakukan oleh (Herman, 2012) didapatkan hasil bahwa promosi jabatan memberikan pengaruh kepada terjadinya kinerja karyawan dan hal yang sama juga terjadi pada variabel kompensasi yang juga memberikan pengaruh terhadap terjadinya kinerja, dan secara bersama sama (variabel kompensasi dan promosi kerja) memberikan pengaruh terhadap variabel kinerja karyawan. Lalu dalam penelitian yang lain seperti dari hasil penelitian yang dilakukan oleh (Zebua, 2020) pada PT Perkebunan Nusantara III Labuhan Haji Kabupaten Labuhanbatu Utara Haji didapatkan hasil yaitu secara parsial variabel promosi jabatan berpengaruh positif dan signifikan terhadap terbentuknya variabel kinerja karyawan.

Tabel 5. Hasil Uji Regresi

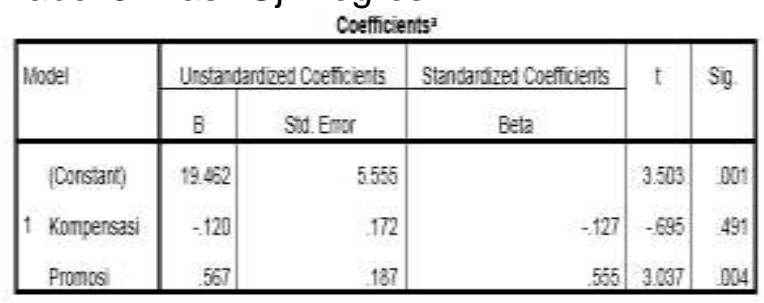

a. Dependent Variable Kinera
Berdasarkan hasil diatas didapatkan persamaan baru yaitu $Y=19.462+0,120+$ 0,567 dimana artinya dalah bila dalam keadaan tertentu dalam perusahaan (tidak ada variabel kompensasi dan promosi jabatan) maka terdapat angka sebenar 19.462 atas variabel kinerja karyawan. Sedangkan untuk nilai kompensasi sebenar 0,120 dan nilai promosi sebesar 0,567 . Dari tabel ini juga dapat dilihat bila pada variabel kompensasi mengalami kenaikan sebesar 1 kali maka akan merubah hasil variabel kinerja menjadi bertambah 0,120 dan hal yang sama juga terjadi pada variabel promosi, apabila pada variabel promosi mengalami kenail sebesar 1 satuan maka akan membuat variabel kinerja mengalami kenaikan sebesar 0,567 .

Hasil dari tabel ini sejalan dengan hasil dari penelitian sebelunya dimana promosi jabatan memberikan pengaruh kepada variabel kinerja. Dalam hasil penelitian yang dilakukan oleh (Martina, 2017) didapatkan hasil uji regresi adalah persamaan $Y=0,515$ $+0.064 X$. dan dari tes didapatkan hasil bahwa promosi jabatan memberikan pengaruh kepada kinerja karyawan pada PT Tasma Puja di Pekanbaru. Apabila variabel promosi jabatan mengalami pertambahan 1 satuan maka akan membuat variabel kinerja naik sebesar 0,064.

\section{KESIMPULAN}

Berdasarkan hasil dan pembahasan pada bagian sebelumnya dapat disimpulkan berapa hal yang dirasakan memiliki korelasi terhadapa pembahasan, adapun beberapa kesimpulan tersebut adalah:

1. Terdapat hubungan dan pengaruh dari variabel Kompensasi dan Promosi jabatan terhadap kinerja karyawan.

2. Perlu adanya upaya yang baik dari perusahaan untuk meningkatkan kinerja karyawan dengan upaya meningkatkan kompensasi dan atau promosi jabatan didalam perusahaan.

\section{DAFTAR PUSTAKA}

Badriyah, M. (2017). Manajemen Sumber Daya Manusia. Bandung: Pustaka Setia.

Fahmi, I. (2016). Perilaku Organisasi. Bandung: Alfabeta.

Hasibuan, M. (2016). Manajemen Sumber 
Daya Manusia. Jakarta: Bumi Aksara.

Herman, N. Y. (n.d.). Pengaruh Promosi Jabatan Dan Kompensasi Terhadap Kinerja Karyawan (Studi pada Giant Ekstra Nangka Pekanbaru). Jurnal Online Mahasiswa. Retrieved from https://jom.unri.ac.id/index.php/JOMFSIP/ article/view/15679/15221

Kadarisman. (2018). Manajemen Kompensasi. Jakarta: Raja Grafindo Persada.

Mahargya, A. P. (2016). Pengaruh Promosi Jabatan Dan Kompensasi Terhadap Kinerja Karyawan Melalui Motivasi (Studi Pada Ria Djenaka Shining Batu, Jawa Timur). Jurnal Ilmiah Mahasiswa FEB, 4(1). Retrieved from https://jimfeb.ub.ac.id/index.php/jimfeb/art icle/view/2500/2271

Mangkunegara, A. P. (2015). Manajemen Sumber Daya Manusia Perusahaan. Bandung: PT Remaja Rosdakarya.

Mangkunegara, A. P. (2019). Evaluasi kinerja SDM. Bandung: Aditama.

Mansyur, A. (2020). Efektivitas Kepemimpinan Dan Kompensasi Insentif Terhadap Kinerja Karyawan Pada Pt. Bni Cabang Panakukang Makassar. Jurnal Administrasi Bisnis, 5(5). Retrieved from http://ojs.uho.ac.id/index.php/BUSSINES UHO/article/view/12405

Martina, A. B. (2017). Pengaruh Promosi Jabatan Terhadap Kinerja Karyawan Pada Pt Tasma Puja Di Pekanbaru. Jurnal Menara IImu, 11(76). Retrieved from https://jurnal.umsb.ac.id/index.php/menar ailmu/article/view/296

Rahayu, S. (2017). Pengaruh Promosi
Jabatan Terhadap Kinerja Karyawan Pada Pt. Garuda Metalindo. Jurnal Kreatif, 5(1). Retrieved from http://openjournal.unpam.ac.id/index.php/ kreatif/article/view/701

Sutrisno, E. (2016). Manajemen Sumber Daya Manusia (8th ed.). Jakarta: Kencana.

Talashina, H. E. (2020). Pengaruh Kompensasi Dan Motivasi Kerja Terhadap Kinerja Karyawan Melalui Kepuasan Kerja Sebagai Variabel Intervening (Studi: Perawat Rs Telogorejo Semarang). Jurnal IImu Administrasi Bisnis, 9(1). Retrieved from

https://ejournal3.undip.ac.id/index.php/jia b/article/view/26359/23298

Vahdist, R. (2017). Pengaruh Gaji, Tunjangan, Dan Promosi Jabatan Terhadap Kinerja Pegawai (Studi pada Badan Kepegawaian Daerah Provinsi Jawa Tengah). Diponegoro Journal of Management.

Wibowo. (2017). Manajemen Kinerja (kelima). Jakarta: Raja Grafindo Persada.

Zebua, Y. (2020). Pengaruh Budaya Kerja Dan Promosi Jabatan Dalam Meningkatkan Kinerja Karyawan Pada Pt. Perkebunan Nusantara lii Labuhan Haji Labuhanbatu Utara. Ecobisma, 7(2). Retrieved from http://jurnal.ulb.ac.id/index.php/ecobisma/ article/view/1758/1717 